\title{
Preliminary Study of Hydrometallurgical Extraction of Silver from Selected E-Waste
}

\author{
Igor WACHTER ${ }^{1}$, Tomáš ŠTEFKO ${ }^{2}$, Teagan MACDONALD ${ }^{3}$ and Maroš SOLDÁN ${ }^{4}$
}

Authors' affiliations and addresses:

${ }^{1}$ Slovak University of Technology in

Bratislava, Faculty of Materials Science and

Technology in Trnava, Institute of Integrated

Safety, Jána Bottu Street, number 2781/25, 917

24 Trnava, Slovakia

e-mail: igor.wachter@stuba.sk

${ }^{2}$ Slovak University of Technology in Bratislava, Faculty of Materials Science and Technology in Trnava, Institute of Integrated Safety, Jána Bottu Street, number 2781/25, 917 24 Trnava, Slovakia

e-mail: tomas.stefko@stuba.sk

${ }^{3}$ The University of Queensland, Australia, School of Civil Engineering, Building 49 Advanced Engineering Building, Staff House Road, St Lucia QLD 4072, Australia e-mail: 4318707@student.uq.edu.au

${ }^{4}$ Slovak University of Technology in Bratislava, Faculty of Materials Science and Technology in Trnava, Institute of Integrated Safety, Jána Bottu Street, number 2781/25, 917

24 Trnava, Slovakia

e-mail: maros.soldan@stuba.sk

\section{*Correspondence:}

Igor Wachter, Slovak University of Technology in Bratislava, Faculty of Materials Science and Technology in Trnava, Institute of Integrated Safety, Jána Bottu Street, number 2781/25, 917 24 Trnava, Slovakia

tel: +421906 068

e-mail: igor.wachter@stuba.sk

\section{Acknowledgment:}

This work was supported by the Slovak Research and Development Agency under the contract No. APVV-16-0223.

This work was supported by the Mladý výskumník, int. č. 1342 (Young Researcher, number 1342).

How to cite this article:

Wachter, J., Štefko, T., Macdonald, T. and Soldán, M. (2020). Preliminary Study of Hydrometallurgical Extraction of Silver from Selected E-Waste. Acta Montanistica Slovaca, Volume 25 (2), 182-191

DOI:

https://doi.org/10.46544/AMS.v25i2.5

\begin{abstract}
Electronic relays (ER) are a type of switch which are an essential part of electronic devices used to open or close circuits by using electronic components without any mechanical operation. After decommissioning, it can be considered as an important source of base and precious metals with high economic value. The annual growth rate of about $4-5 \%$ in 2016 is one of the fastest growing waste stream, and only about $20 \%$ of e-waste is recycled. After the use-phase, electronic devices become electronic waste (e-waste); consequently, it is important to consider e-waste as a secondary supply for the recovery of precious metals. In this study, a simple hydrometallurgical recovery method for silver $(\mathrm{Ag})$ extracting from used electronic relays was performed. The silver extractions consisted of six stages: disassembling of relays, removal of base metals, leaching in nitric acid, precipitation, conversion silver oxide and melting. Measurements of extracted precious metals were carried out by scanning electron microscope (SEM) and EDS (Energy Dispersive Spectrum) analysis. The purity rate of the final deposit was $94.9 \%$ on the surface of the sample, and the final silver recovery yielded $0.44 \%$ of the raw material. During the second stage of the experiment, mixed types of electronic relays were used to compare the yields. Electronic relays can be considered as an important source of base and precious metals with high economic value. The final yield of the mixed electronic relays reached up to $0.54 \%$ of $\mathrm{Ag}$ with the purity of over $95 \%$.
\end{abstract}

\section{Keywords}

E-waste, EDS analysis, Hydrometallurgy, Recycling, Silver extraction 


\section{Introduction}

E-waste has been a major segment of the waste produced in the past decades (Widmer et al., 2005) (Behnamfard et al., 2013). In recent years a huge growth in the use of many information and communication technology products has been observed. In the European Union, approximately 8 million tonnes of e-waste are generated every year with an annual increase of $3-5 \%$ ( Drechsel, 2006) while approximately $20-50$ million metric tonnes of e-waste are generated worldwide (Petraniková, 2008). There are also growing concerns about the e-waste generated in developed countries due to the lack of infrastructure for environmentally sound management of e-waste. The reasons for decreasing life span of electrical and electronic devices are as follows (Akcil et al., 2015, Ivanova et al., 2018):

- Incoming of highly advanced and technically skilled devices/equipment at a lower price and more features.

- Rapid growth in the lifestyle of human beings with modern facilities having user-friendly electrical and electronic equipment.

- Stiff competition amongst individuals to use and small enterprises and industries to produce and sell the best products made on advanced technologies.

WEEE (Waste of electric-electronic equipment) contains a variety $(>1000)$ of organic and inorganic substances with its composition depending largely on the type, manufacturer and age of the equipment (Table 1). WEEE can contain up to $61 \%$ metals and $21 \%$ plastics (Widmer et al., 2005, Biały et al., 2019, Biały et al., 2019a). Polyethylene, polypropylene, polyesters and polycarbonates are typical plastic components (Gramatyka et al., 2007, Sviatskii et al., 2020). Many of the materials such as chlorinated and brominated substances, toxic metals, photoactive and biologically active materials, acids, plastics and plastic additives present in WEEE are highly toxic.

Table 1. Material composition of WEEE (Widmer et al., 2005)

\begin{tabular}{c|c}
\hline Material & Content [\%] \\
\hline Metals & \\
Iron and steel & 47.9 \\
Copper & 7.0 \\
Aluminium & 4.7 \\
Non-ferrous & 1.0 \\
Total & 60.6 \\
& \\
Plastics & \\
Flame retarded plastics & 5.3 \\
Non-flame retarded plastics & 15.3 \\
Total plastics & 20.6 \\
Glass & 5.4 \\
Rubber & 0.9 \\
Wood and plywood & 2.6 \\
Ceramic & 2.0 \\
Printed circuit boards & 3.1 \\
Other & 4.6
\end{tabular}

E-waste encompasses valuable metals, alongside numerous dangerous materials. An enormous number of dangerous metals $(\mathrm{Cd}, \mathrm{Hg}, \mathrm{Pb}, \mathrm{Cr})$ from e-waste may contribute to increasing the toxicity levels of the ecosystem (Qu et al., 2019). E-waste material in the environment may increase the exposure risk of hazardous materials. Serious pollution of groundwater and human health could be associated with these hazardous materials. One of the important routes to enter toxic chemicals from e-waste to the human body is the soil-crop-food pathway. Toxicity, negative environmental impact, as well as financial reimbursements from e-waste, are necessitated the need for metal recovery from e-waste. The utilization of e-waste could be a potential secondary source of precious and base metals (Otto et al., 2018). Without knowing the hurtful impact, E-waste has been discarded in the open wellsprings of water bodies, the agricultural land, and open landfills by unconscious social people. For the open disposal of the e-waste containing toxic substances in water bodies and landfills pollutes the groundwater (Romaric et al., 2019), as shown in Fig. 1. 


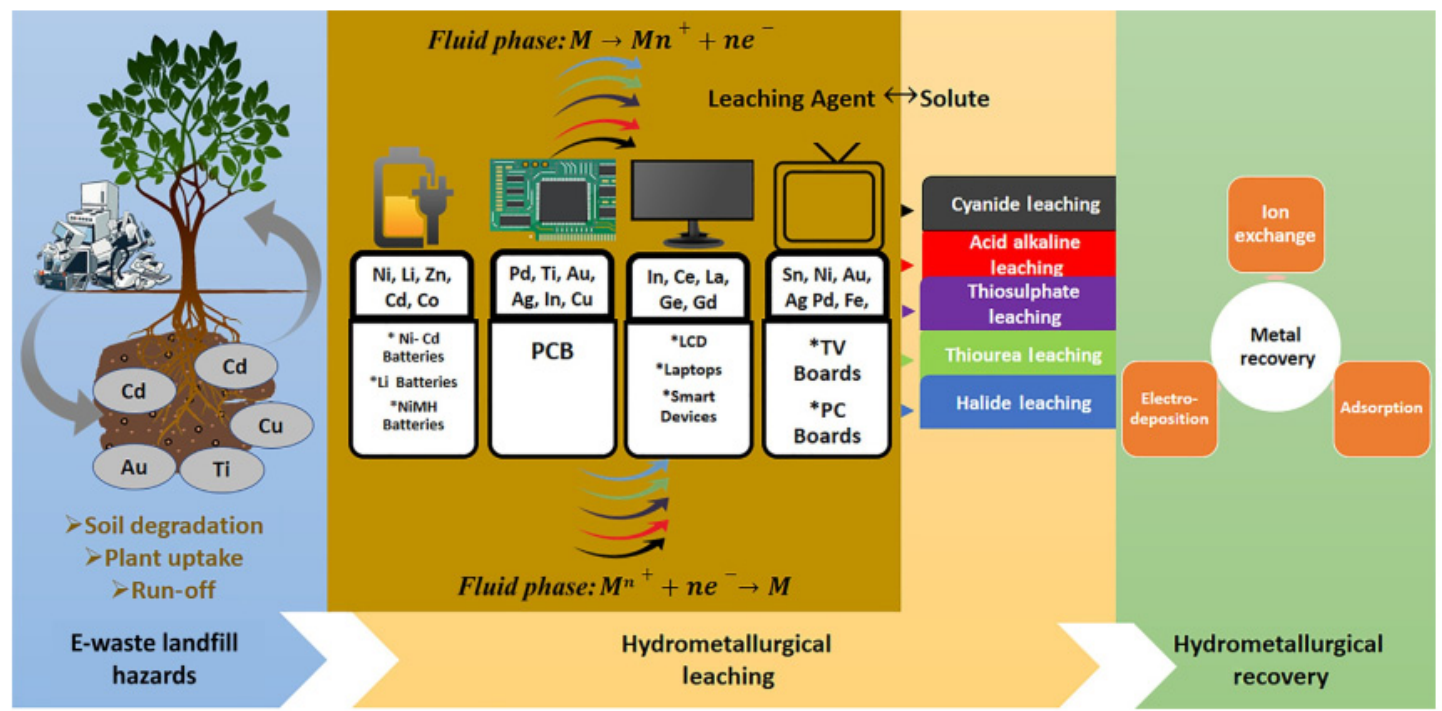

Fig. 1. E-waste from landfills to resource recovery (Ashiq et al., 2019)

E-waste from such equipment contains many toxic elements such as lead, mercury, cadmium, nickel, chromium, etc., which has an adverse impact on our environment. Moreover, e-waste also contains many valuable metals, such as gold, silver, platinum, and palladium (Tripathi et al., 2012). The proper management of discarded electronic devices is an emerging issue for solid waste professionals throughout the world because of the large growth of the waste stream, and the content of toxic metals in them, most notably heavy metals such as lead (Jang and Townsend, 2006). Harmful effects of various metals present in the electronic waste on human health are summarized in Table 2.

Table 2. Hazardous substances and their possible adverse effects (Kaya, 2016)

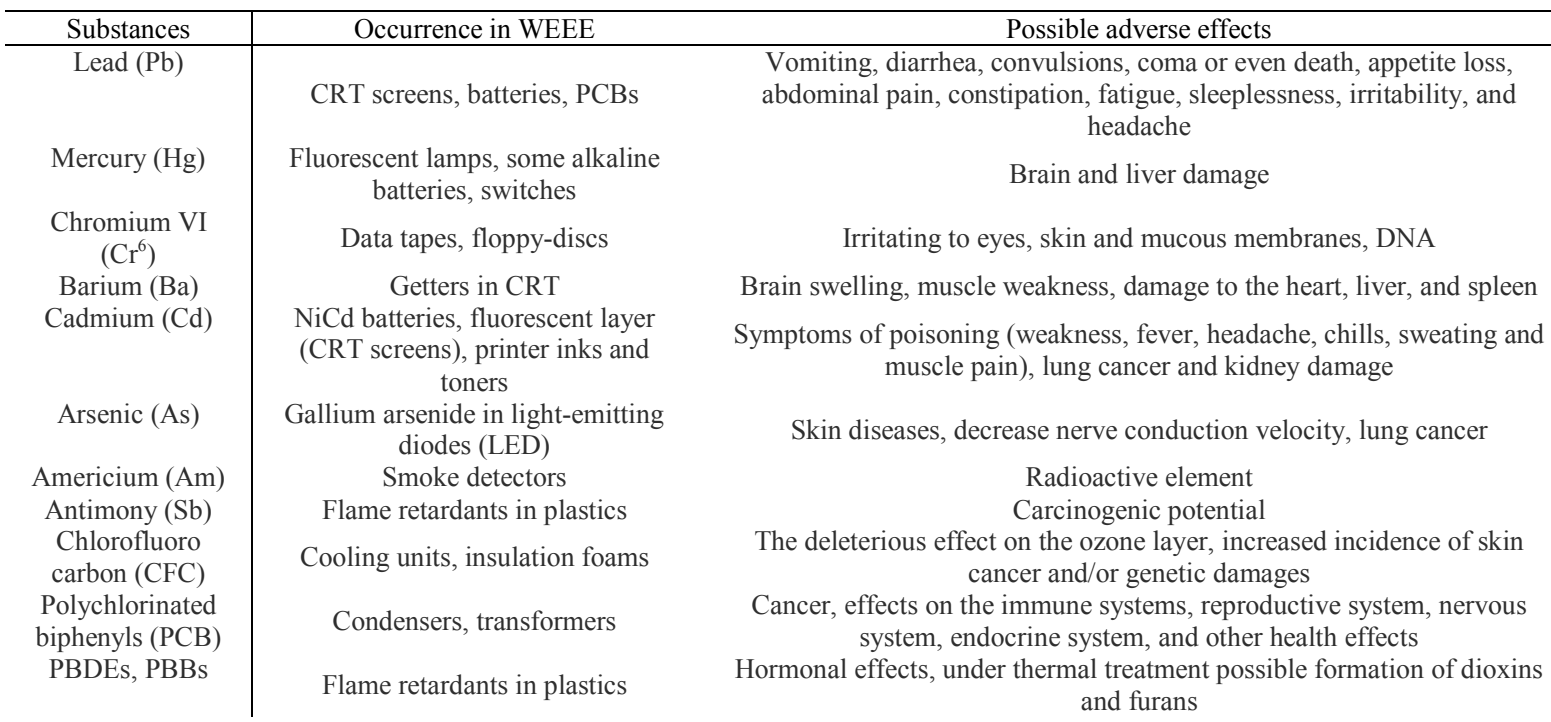

Currently, e-waste recycling focuses mainly on mechanical approaches, pyro-metallurgy, bio-metallurgy, and hydro-metallurgy (Hsu et al., 2019; Liu et al., 2019). The reason for preference of hydro-metallurgy over pyro-metallurgy is because of low or no gas emission compared to pyro process which releases toxic gases (dioxins/furans) and volatile metals, dust, $\mathrm{Cl}_{2}, \mathrm{Br}_{2}, \mathrm{SO}_{2}$ and $\mathrm{CO}_{2}$ together with others $\mathrm{Pb}, \mathrm{Hg}, \mathrm{Cr}^{6+}, \mathrm{Cd}$, flame retardants. No dust or low dust generation, low energy consumption, high recovery rate, no slag generation except few plastics, and easy working conditions (Ni et al., 2013; Tue et al., 2013; Zhang et al., 2012). According to these studies (Andrews et al., 2000; Cui and Zhang, 2008), hydro-metallurgy could be preferred over pyro-metallurgy for the recovery of precious metals such as gold, silver, and platinum. 
Table 3. Development of global silver demand by sectors (2011 - 2019) (The Silver Institute and The Materials Focus, 2020)

\begin{tabular}{|c|c|c|c|c|c|c|c|c|c|}
\hline Metric t & 2011 & 2012 & 2013 & 2014 & 2015 & 2016 & 2017 & 2018 & 2019 \\
\hline Industrial & 15804 & 14012 & 14332 & 13984 & 14189 & 15250 & 16087 & 15909 & 15891 \\
\hline $\begin{array}{l}\text {...of which } \\
\text { photovoltaics }\end{array}$ & 2127 & 1711 & 1571 & 1505 & 1683 & 2914 & 3166 & 2877 & 3070 \\
\hline Photography & 1916 & 1633 & 1425 & 1356 & 1281 & 1176 & 1092 & 1064 & 1048 \\
\hline Jewellery & 5045 & 4952 & 5819 & 6018 & 6302 & 5885 & 6106 & 6317 & 6261 \\
\hline Silverware & 1291 & 1247 & 1421 & 1630 & 1760 & 1627 & 1795 & 2034 & 1860 \\
\hline $\begin{array}{l}\text { Net physical } \\
\text { investment }\end{array}$ & 8460 & 7490 & 9334 & 8790 & 9654 & 6653 & 4858 & 5154 & 5788 \\
\hline TOTAL & 32515 & 30590 & 33246 & 31775 & 33187 & 30963 & 30005 & 30739 & 30848 \\
\hline
\end{tabular}

Table 4 shows the development in global silver supply by the sources During the last decade $(2011-2019)$. Global recycling edged higher last year (2019), up $1.3 \%$ to 5,284t. Volumes from industrial end-uses, the biggest source of scrap, rose $2 \%$ to the highest level this decade (The Silver Institute, 2020).

Table 4. Development of global silver supply by sources (2011 - 2019) (The Silver Institute and The Materials Focus, 2020)

\begin{tabular}{c|ccccccccc}
\hline Metric $\mathrm{t}$ & 2011 & 2012 & 2013 & 2014 & 2015 & 2016 & 2017 & 2018 & 2019 \\
\hline $\begin{array}{c}\text { Mine } \\
\text { production }\end{array}$ & 23642 & 24656 & 26136 & 27293 & 27772 & 27753 & 26855 & 26369 & 26018 \\
Recycling & 7244 & 6718 & 5994 & 5440 & 5179 & 5113 & 5216 & 5216 & 5284 \\
Net hedging & 370 & - & - & 333 & 68 & - & - & - & 488 \\
supply & 31405 & 31489 & 32183 & 33100 & 33050 & 32901 & 32105 & 31626 & 31822 \\
TOTAL & 3142
\end{tabular}

Spent electronic equipment consists of several components in the form of metals and multicomponent elements. The base metals include iron, aluminum, nickel, zinc, selenium, indium, and gallium. The noble metals can be divided into copper, palladium, or gold, silver. Hazardous substances that can be found in spent electronic equipment include mercury, beryllium, lead, arsenic, cadmium, antimony and plastics, glass, and ceramics. Depending on many factors, such as the age of the device, manufacturer, or the type of equipment, the content of the individual electronic component in the waste is mixed (Fornalczyk et al., 2013). Spent electronic equipment consists of several components in the form of metals and multicomponent elements. The base metals include iron, aluminum, nickel, zinc, selenium, indium, and gallium. The noble metals can be divided into copper, palladium, or gold, silver. Hazardous substances that can be found in spent electronic equipment include mercury, beryllium, lead, arsenic, cadmium, antimony, and plastics (Fornalczyk et al., 2013). Table 2 shows the selected material composition of electronic devices. A decisive impact on the value of electronic scrap has the content of precious metals, although iron and plastic are dominant components, and a seemingly small content of precious metals in different electronic devices $(<0.5 \%)$.

Table 5. Composition of metals from different e-waste samples (Cui and Zhang, 2008)

\begin{tabular}{|c|c|c|c|c|c|c|c|c|}
\hline \multirow{2}{*}{ E-waste } & \multicolumn{5}{|c|}{ Weight $[\%]$} & \multicolumn{3}{|c|}{ Weight [ppm] } \\
\hline & $\mathrm{Fe}$ & $\mathrm{Cu}$ & $\mathrm{Al}$ & $\mathrm{Pb}$ & $\mathrm{Ni}$ & $\mathrm{Ag}$ & $\mathrm{Au}$ & $\mathrm{Pd}$ \\
\hline TV board scrap & 28 & 10 & 10 & 1.0 & 0.3 & 280 & 20 & 10 \\
\hline PC board scrap & 7 & 20 & 5 & 1.5 & 1 & 1000 & 250 & 110 \\
\hline Mobile phone scrap & 5 & 13 & 1 & 0.3 & 0.1 & 1380 & 350 & 210 \\
\hline Portable audio scrap & 23 & 21 & 1 & 0.14 & 0.03 & 150 & 10 & 4 \\
\hline DVD player scrap & 62 & 5 & 2 & 0.3 & 0.05 & 115 & 15 & 4 \\
\hline Calculator scrap & 4 & 3 & 5 & 0.1 & 0.5 & 260 & 50 & 5 \\
\hline PC mainboard scrap & 4.5 & 14.3 & 2.8 & 2.5 & 1.1 & 639 & 566 & 124 \\
\hline Printed circuit boards & 12 & 10 & 7 & 1.2 & 0.85 & 280 & 110 & - \\
\hline Printed circuit boards & 5.3 & 26.8 & 1.9 & - & 0.47 & 3300 & 80 & - \\
\hline
\end{tabular}

Although iron and plastic are dominant components, in terms of weight, a seemingly small content of precious metals in different electronic devices $(<0.5 \%)$, constitutes about the electronic scrap value (Table 4) (Fornalczyk and Saternus, 2013). Analysing only computer equipment and mobile phones, this share is $3 \%$ of the world's production for Ag, $4 \%$ for Au, and $16 \%$ for Pd. In 2019 the global silver demand was 30848 metric tonnes (Table 3). The highest demand is in long-termed achieved in the industry, which also includes the electronics and IT sector. 
More than ten times higher purity of precious metals in waste printed circuit boards compared to the rich ore content attract the attention to extract noble metal from e-waste. Hence, the extraction of noble metals (Au, $\mathrm{Pt}, \mathrm{Pd}, \mathrm{Ta}, \mathrm{Te}, \mathrm{Ge}, \mathrm{Se}$ ) from e-waste should be given major priorities. However, the realization of recycling should be the basis of maximum recovery and minimum negative impact on the environment (Islam et al., 2020). This paper discusses the extraction of silver from used electronic relays via a simple hydrometallurgical process. The objective was to determine the relative amount of Ag recoverable from this type of waste.

\section{Material and Methods}

Chemical leaching (Fig. 2) involves leaching either by using acid or ligand supported complexation. Chemical leaching of metals from E-waste can also be done by utilizing various inorganic-acids.

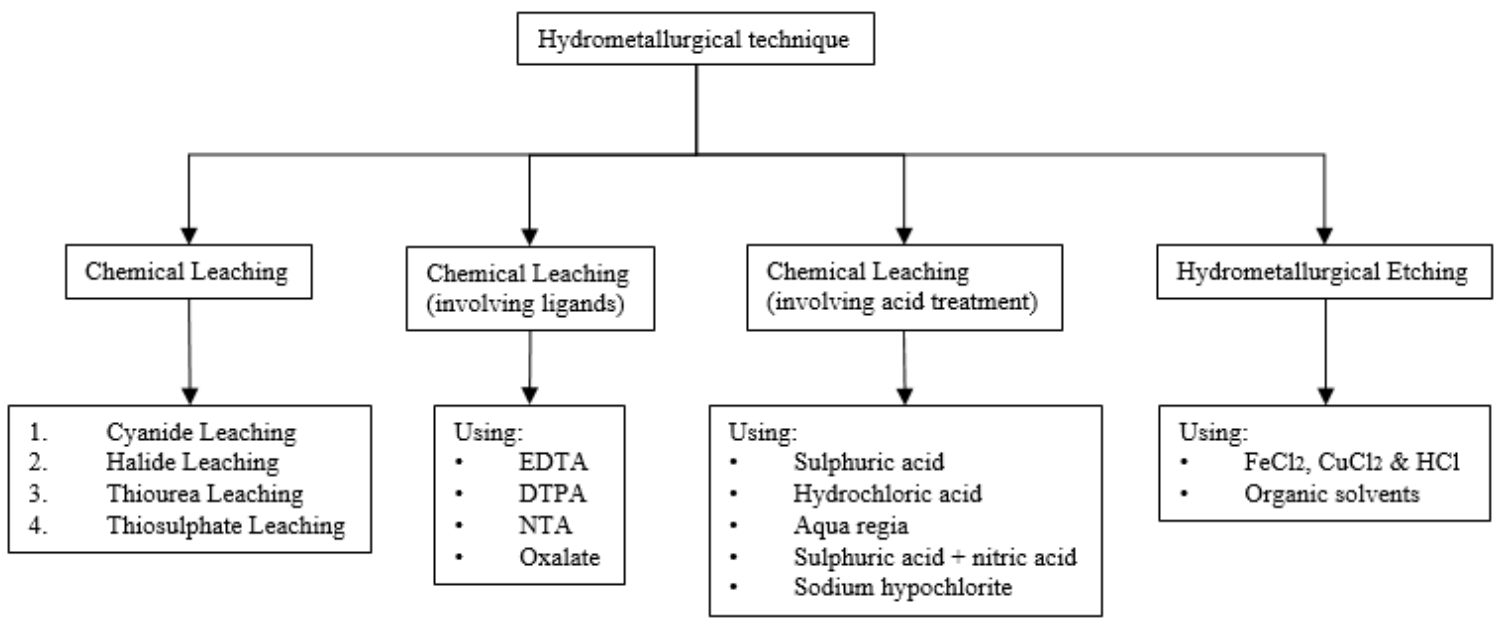

Fig. 2. Types of hydrometallurgical techniques

In this paper, two sets of electrical relays were used to extract silver by hydrometallurgical acidic techniques. The difference in the two sets was in the used precipitation of the silver from the pregnant leach solution.

The first set consisted of seven commercially used electrical relays (Allen-Bradley 700-HA33Z2-3) containing nine silver contacts made of silver, copper, nickel, and aluminum. The weight of the whole relay was 86.74 grams. The experimental procedure consisted of six main steps. All of the used chemicals were purchased from CentralChem s.r.o. The used chemicals were of analytical grade. After collecting the raw material, the relays were manually disassembled, and the silver-containing contacts were collected in a beaker. To remove all of the base and redundant metals except silver, the contacts were treated by concentrated hydrochloride acid $+35 \%$ hydrogen peroxide $(100 \mathrm{ml}+5 \mathrm{ml})$. The beaker was placed on a heating plate to accelerate the reaction of metals removal. Chemicals were added and heated until no visible signs of reaction were observed, and only silvery metal was present. The contacts were then washed three times with distilled water, and in the next step, concentrated nitric acid with distilled water $(50 \mathrm{ml}+50 \mathrm{ml})$ were added to the beaker with the contacts. After two hours, the contacts were completely dissolved in the solution in the form of silver(I) nitrate $\left(\mathrm{AgNO}_{3}\right)$. To precipitate the silver(I) nitrate from the solution, a concentrated hydrochloric acid was used to produce $\mathrm{AgCl}$ (silver(I) chloride). After three washings with boiling distilled water, sodium hydroxide $(\mathrm{NaOH})$ was added to convert $\mathrm{AgCl}$ to silver(II) oxide $\left(\mathrm{Ag}_{2} \mathrm{O}\right)$. As a final step, the silver oxide dust was placed into a melting dish and melted at a temperature of $980{ }^{\circ} \mathrm{C}$ to form a single bead of silver using a muffle furnace. Analysis of the metal was performed using a scanning electron microscope (SEM) and energy dispersive spectrum (EDS) analysis. The main individual steps and corresponding reactions of the procedure are shown in Table 6.

Table 6. Main steps of the silver extraction from electrical relays ( $1^{\text {st }}$ set)

\begin{tabular}{c|cc}
\hline NR. & OPERATION & MAIN REACTION \\
\hline 1. & Disassembly of relays & - \\
& Removal of redundant metals by hydrochloride acid + & $\mathrm{H}_{2} \mathrm{O}_{2}+\mathrm{Cu}+2 \mathrm{HCl} \rightarrow \mathrm{CuCl}+2 \mathrm{H}_{2} \mathrm{O}$ \\
2. & hydrogen peroxide & $\mathrm{H}_{2} \mathrm{O}_{2}+\mathrm{Ni}+2 \mathrm{HCl} \rightarrow \mathrm{NiCl}+2 \mathrm{H}_{2} \mathrm{O}$ \\
& Dissolving in nitric acid & $3 \mathrm{H}_{2} \mathrm{O}_{2}+2 \mathrm{Al}+6 \mathrm{HCl} \rightarrow 2 \mathrm{AlCl}_{3}+6 \mathrm{H}_{2} \mathrm{O}$ \\
3. & $\mathrm{Ag}+2 \mathrm{HNO}_{3} \rightarrow \mathrm{AgNO}_{3}+\mathrm{NO}_{2}+\mathrm{H}_{2} \mathrm{O}$ \\
4. & Precipitation with hydrochloric acid & $\mathrm{AgNO}_{3}+\mathrm{HCl} \rightarrow \mathrm{AgCl}+\mathrm{HNO}$ \\
5. & Conversion with sodium hydroxide & $2 \mathrm{AgCl}+2 \mathrm{NaOH} \rightarrow \mathrm{Ag} \mathrm{H}_{2} \mathrm{O}+\mathrm{H}_{2} \mathrm{O}+2 \mathrm{NaCl}$ \\
6. & Melting & $2 \mathrm{Ag}_{2} \mathrm{O} \rightarrow$ t $^{\circ} \mathrm{C} \rightarrow 4 \mathrm{Ag}+\mathrm{O}_{2}$
\end{tabular}


In the second stage of the research, ten electrical relays, each containing nine contacts made of silver, copper, nickel, and aluminum were used. The weight of the whole relay was 86.74 grams. The experimental procedure consisted of four main steps. All chemicals (analytical grade) were purchased from CentralChem s.r.o. Contacts were mechanically trimmed from relays, put in a beaker, and treated by a mixture of concentrated $\mathrm{HCl}$ and $35 \% \mathrm{H}_{2} \mathrm{O}_{2}(100 \mathrm{ml}+5 \mathrm{ml})$ to remove all the base metals. The solution was heated by a heating plate to increase the reaction speed. After the removal of all metals, the residual silver coatings were washed by distilled water. In the next step, concentrated $\mathrm{HNO}_{3}$ with distilled water (ratio 1:1) was used to dissolve the silver. After two hours, all silver was completely dissolved, forming silver(I) nitrate $\left(\mathrm{AgNO}_{3}\right)$. In this case, pure metallic silver was obtained from the solution by cementing on a solid copper cylinder. Obtained silver was washed by hot distilled water three times and subsequently melted into one bead. The main individual steps and corresponding reactions of the procedure are shown in Table 7.

Table 7. Main steps and corresponding reactions used to extract silver from electrical relays $\left(2^{\text {nd }}\right.$ set $)$

\begin{tabular}{c|cc}
\hline Nr. & Operation & Main reaction \\
\hline 1. & Mechanical separation of contacts & - \\
& & \\
2. & Removal of redundant metals by $\mathrm{HCl}+35 \% \mathrm{H}_{2} \mathrm{O}_{2}$ & $\mathrm{H}_{2} \mathrm{O}_{2}+\mathrm{Cu}+2 \mathrm{HCl} \rightarrow \mathrm{CuCl}+2 \mathrm{H} \mathrm{H}_{2} \mathrm{O}$ \\
$\mathrm{H}_{2} \mathrm{O}_{2}+\mathrm{Ni}+2 \mathrm{HCl} \rightarrow \mathrm{NiCl}+2 \mathrm{H}_{2} \mathrm{O}$ \\
3.
\end{tabular}

The summarised flowchart of the processes is shown in the Figure 4.

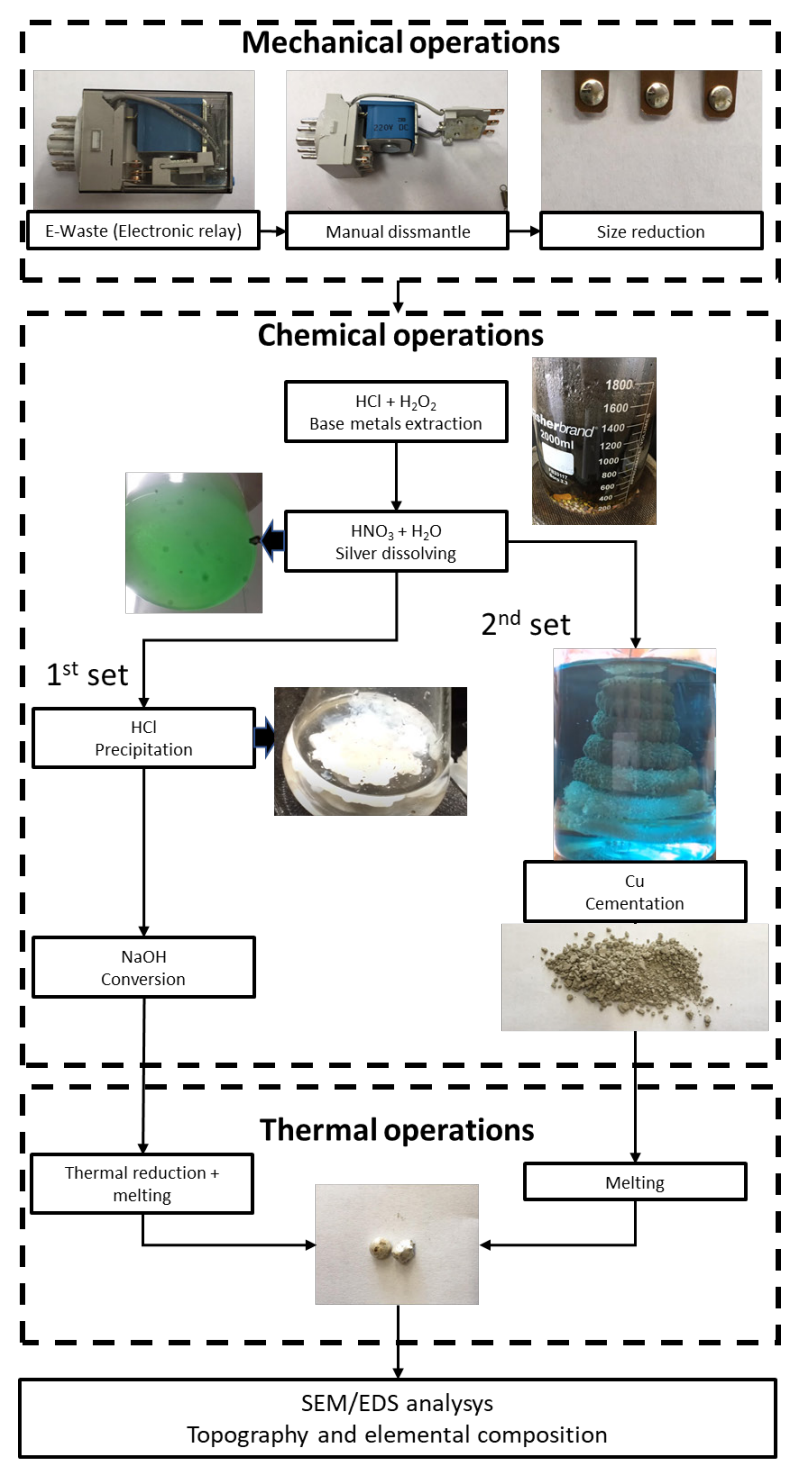

Fig. 3. Flowchart of the experiments 


\section{Results and Discussion}

Researchers have indicated that effective recovery of precious metals from e-waste is feasible (Ficeriová et al., 2011, 2005; Ficeriová and Baláž, 2010). To illustrate, printed circuit board (PCB) of a PC can contain up to $20 \% \mathrm{Cu}$ and $250 \mathrm{~g} /$ ton $\mathrm{Au}$, which are significantly high, i.e. 25-250-fold for gold and 20-40-fold for copper when compared with gold ores $(1-10 \mathrm{~g} /$ ton $\mathrm{Au})$ and copper ores $(0.5-1 \% \mathrm{Cu})$, respectively. Recycling turns WEEE into a secondary resource allowing the recovery and reuse of metals and non-metals contained and mitigating the environmental impact of WEEE (Cui and Zhang, 2008; Havlík et al., 2010; Yazici et al., 2010).

The recovery yield of silver obtained from the first set of electrical relays reached $0.44 \%$. In each of seven electrical relays, there are nine silver-containing contacts made of silver, copper, nickel, and aluminum. The total weight of one whole relay was $86.744 \mathrm{~g}$ (seven relays weight $607.21 \mathrm{~g}$ ). After mechanical removal of the nine silver-bearing contacts, its weight was $2.892 \mathrm{~g}$ (63 pieces of contacts weight $182.196 \mathrm{~g}$ ). After acid - peroxide bath, the contacts weighed $3.981 \mathrm{~g}$. In total, $2.667 \mathrm{~g}$ of silver was extracted from the material by this process. Electrical relay mainly consists of circuitry, plastic, and base metals, which makes it easily recyclable e-waste. This kind of e-waste becomes a valuable material for further processing of basic mechanical separation. Therefore, an estimated concentration of silver in this type of relay is $4400 \mathrm{~g} / \mathrm{t}$.

The recovery yield of silver obtained from the second set of electrical relays reached $0.54 \%$. The total weight of ten relays was $921.35 \mathrm{~g}$. The total weight of separated contacts ( 90 pieces) was approximately $25.4 \mathrm{~g}$. In total, $4.79 \mathrm{~g}$ of silver was extracted from the material by this process, which is $5200 \mathrm{~g} / \mathrm{t}$ (from the total weight).

Cui et al. (2008) determined the amount of $\mathrm{Ag}$ in different e-waste samples to be comparable or lower than in keyboards. Li et al. (2019), reported that CPU sockets also contain silver (431 g/t) with a lower yield. For the mining sector, the silver reserves are divided into known reserves and hidden reserves and stratified into four levels of ore quality: 1 . Rich silver is labeled as extra high quality $(10,000-6000 \mathrm{~g} / \mathrm{t}), 2$. High grade $(1100-800$ $\mathrm{g} / \mathrm{t}), 3$. Low grade $(100-80 \mathrm{~g} / \mathrm{t})$ and 4 . Ultra-low grade (below $10-8 \mathrm{~g} / \mathrm{t}$ ), which means this type of e-waste could be considered to be an extra high-quality source of silver (Sverdrup et al., 2014). As shown in Table 8, copper and precious metals contribute invariably and extensively to the economic potential of all WEEE.

Table 8. Composition of metals from different e-waste samples

\begin{tabular}{|c|c|c|c|c|c|c|c|c|c|}
\hline \multirow[b]{2}{*}{ Type of e-waste } & \multicolumn{9}{|c|}{ Content ( $\%$ or $\mathrm{g} /$ ton $)$ and contribution to economic potential (\%) (in brackets) } \\
\hline & $\mathrm{Fe}(\%)$ & $\mathrm{Cu}(\%)$ & $\mathrm{Al}(\%)$ & $\mathrm{Pb}(\%)$ & $\operatorname{Sn}(\%)$ & $\mathrm{Ni}(\%)$ & $\begin{array}{c}\mathrm{Au} \\
\text { (g/ton) }\end{array}$ & $\begin{array}{c}\mathrm{Ag} \\
\text { (g/ton) }\end{array}$ & $\mathrm{Pd}(\mathrm{g} / \mathrm{ton})$ \\
\hline Price $(\$ / \text { ton })^{\mathrm{a}}$ & 525 & 9211 & 2298 & 242 & 25.900 & 24.180 & $4.9 \times 10^{7}$ & $1.06 \times 10^{6}$ & $2.68 \times 10^{7}$ \\
\hline PC boards & $\begin{array}{c}7 \\
(0)\end{array}$ & $\begin{array}{c}20 \\
(10)\end{array}$ & $\begin{array}{c}5 \\
(1)\end{array}$ & $\begin{array}{l}1.5 \\
(0)\end{array}$ & $\begin{array}{l}2,9 \\
(4)\end{array}$ & $\begin{array}{c}1 \\
(1)\end{array}$ & $\begin{array}{l}250 \\
(64)\end{array}$ & $\begin{array}{c}1000 \\
(5)\end{array}$ & $\begin{array}{c}110 \\
(15)\end{array}$ \\
\hline PC boards & $\begin{array}{l}2.1 \\
(1)\end{array}$ & $\begin{array}{l}18.5 \\
(10)\end{array}$ & $\begin{array}{l}1.3 \\
(0)\end{array}$ & $\begin{array}{l}2.7 \\
(0)\end{array}$ & $\begin{array}{l}4.9 \\
(7)\end{array}$ & $\begin{array}{l}0.4 \\
(1)\end{array}$ & $\begin{array}{c}86 \\
(26)\end{array}$ & $\begin{array}{l}694 \\
(4)\end{array}$ & $\begin{array}{l}309 \\
(51)\end{array}$ \\
\hline TV boards ${ }^{b}$ & $\begin{array}{c}0.04 \\
(0)\end{array}$ & $\begin{array}{l}9.2 \\
(61) \\
\end{array}$ & $\begin{array}{c}0.75 \\
(1)\end{array}$ & $\begin{array}{c}0.003 \\
(0)\end{array}$ & $\begin{array}{l}0.72 \\
(13)\end{array}$ & $\begin{array}{c}0.01 \\
(0)\end{array}$ & $\begin{array}{c}3 \\
(11)\end{array}$ & $\begin{array}{l}86 \\
(7)\end{array}$ & $\begin{array}{l}3.7 \\
(7)\end{array}$ \\
\hline TV boards & $\begin{array}{l}28 \\
(5)\end{array}$ & $\begin{array}{c}10 \\
(28)\end{array}$ & $\begin{array}{l}10 \\
(7)\end{array}$ & $\begin{array}{c}1 \\
(1)\end{array}$ & $\begin{array}{c}1.4 \\
(10)\end{array}$ & $\begin{array}{l}0.3 \\
(2)\end{array}$ & $\begin{array}{c}20 \\
(30)\end{array}$ & $\begin{array}{l}280 \\
(9)\end{array}$ & $\begin{array}{l}10 \\
(8)\end{array}$ \\
\hline $\begin{array}{c}\text { Mobile phones } \\
\text { (1999) }\end{array}$ & $\begin{array}{c}5 \\
(0)\end{array}$ & $\begin{array}{l}13 \\
(5)\end{array}$ & $\begin{array}{c}1 \\
(0)\end{array}$ & $\begin{array}{l}0.3 \\
(0)\end{array}$ & $\begin{array}{l}0.5 \\
(0)\end{array}$ & $\begin{array}{l}0.1 \\
(0)\end{array}$ & $\begin{array}{l}350 \\
(67)\end{array}$ & $\begin{array}{c}1380 \\
(6)\end{array}$ & $\begin{array}{l}210 \\
(22)\end{array}$ \\
\hline $\begin{array}{l}\text { Typical ore } \\
\text { grades }\end{array}$ & 25 & 0.5 & 30 & 5 & 0.5 & 0.5 & 1 & - & - \\
\hline
\end{tabular}

Analysis of the metal beads was performed using a scanning electron microscope (SEM) and energy dispersive spectrum (EDS) analysis (Figure 5). EDS (Energy Dispersive Spectrum) analysis was used to determine the chemical composition and concentration of individual elements. It was performed by the energydispersive X-ray spectroscopy analyzer, which was a part of the scanning electron microscope of JEOL JSM 7600 Ftype. The topography of silver beads was observed at an accelerating voltage of $20 \mathrm{kV}$, current $2 \mathrm{nA}$, and a working distance of approximately $15 \mathrm{~mm}$. The chemical composition of silver bead was investigated by software INCA. 


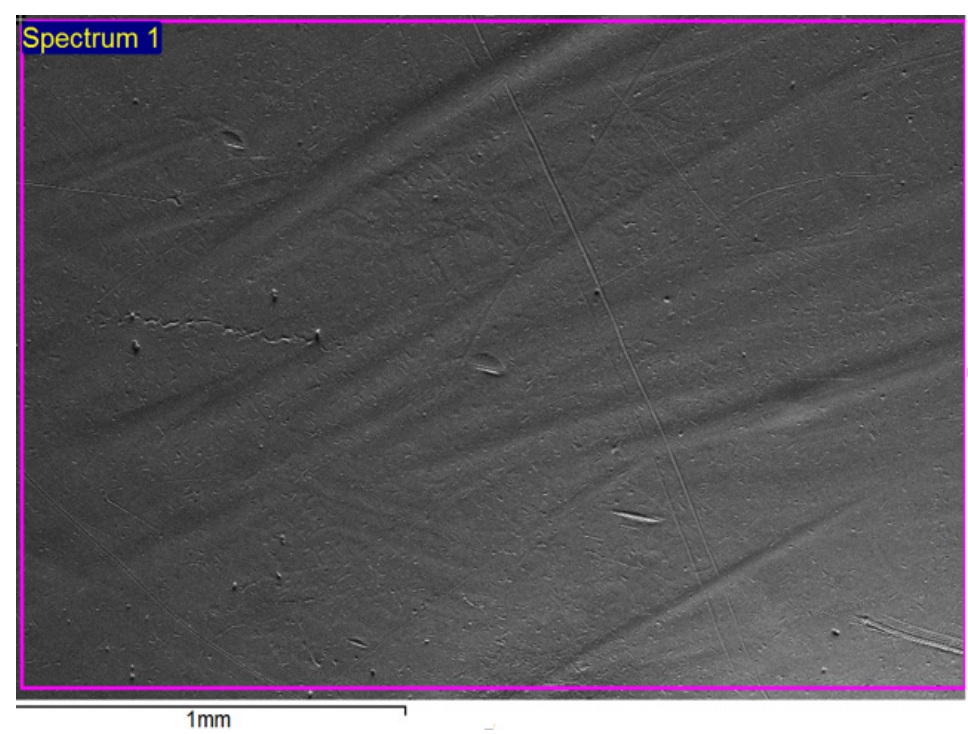

Fig. 4. SEM image of the resulting silver sample ( $1^{\text {st }}$ set)

Table 9 shows the results of EDS analysis. Elemental analysis showed that the purity of obtained silver beads was $88.45 \%\left(1^{\text {st }}\right.$ set $)$ and $\left.95.65 \%\right)\left(2^{\text {nd }}\right.$ set $)$. Because only the surface of the sample is analyzed by this method, it is possible that the sample has a higher purity under the top layer. The presence of oxygen may be caused by the formation of silver oxide, which is produced under normal conditions when silver reacts with the oxygen present in the air. The presence of carbon may be explained by the impurities on the melting cupel from the previous melting. The magnesium also comes from the cupel, which is made of pure and compressed magnesium oxide $(\mathrm{MgO})$.

Table 9. EDS analysis of the silver bead

\begin{tabular}{c|cccccc}
\hline & \multicolumn{5}{c}{ Element content (\%) } \\
\cline { 2 - 6 } & C & O & Mg & Si & Ag & Total \\
\hline Bead 1 & 4.53 & 6.43 & 0.32 & 0.27 & 88.45 & 100.00 \\
Bead 2 & 3.78 & 0.34 & 0.23 & - & 95.65 & 100.00 \\
\hline
\end{tabular}

The waste solution containing dissolved metals from the process was cemented according to the electronegativity series, and as a result, almost zero waste was produced during the whole extraction process.

\section{Conclusion}

At present mechanical and hydrometallurgical separation technologies has a relatively high recovery rate of precious metals, although these methods have not been adopted by countries with low GDP because of its complexity and high economic cost. Hence, recycling this kind of e-waste can both decrease the pressure on natural resources and reduce environmental contamination. This paper presented a simple silver extracting method from electrical relays and determined the quantity of recoverable precious metal. EDS analyses showed the purity of the obtained metal. The advantages of the presented hydrometallurgical method were its costeffectiveness, environmental friendliness, and time-efficiency. We demonstrated that discarded electrical relays contain an appreciable quantity of silver with high economic potential. Using this method, it is possible to extract $4400 \mathrm{~g} / \mathrm{t}-5200 \mathrm{~g} / \mathrm{t}$ of silver from commercially used electrical relays (Allen-Bradley 700-HA33Z2-3) with $88.45 \%$ purity $\left(1^{\text {st }}\right.$ set) and $95.65 \%$ purity $\left(2^{\text {nd }}\right.$ set $)$. The procedure should be further studied for different aspects and for different e-wastes to help with negative impacts on the environment.

\section{References}

Akcil, A., Erust, C., Gahan, C.S., Ozgun, M., Sahin, M., Tuncuk, A., 2015. Precious metal recovery from waste printed circuit boards using cyanide and non-cyanide lixiviants - A review. Waste Manag. 45, $258-271$. https://doi.org/https://doi.org/10.1016/j.wasman.2015.01.017

Andrews, D., Raychaudhuri, A., Frías, C., 2000. Environmentally sound technologies for recycling secondary lead. J. Power Sources 88, 124-129. https://doi.org/https://doi.org/10.1016/S0378-7753(99)00520-0 
Ashiq, A., Kulkarni, J., Vithanage, M., 2019. Hydrometallurgical Recovery of Metals From E-waste. pp. 225246. https://doi.org/10.1016/B978-0-12-816190-6.00010-8

Bialy W, Sovin V.E, Zatsepina V.I, Zatsepin E.P, Shachnev O.Ya.: 2019. „Ensuring efficient operation of electromechanical systems with frequency regulation with periodic voltage sags". E3S Web of Conferences, Volume 124, 2019. International Scientific and Technical Conference Smart Energy Systems 2019 (SES-2019) Article Number 05059, Number of page(s) 5.

Bialy W, Stepanova E.M., Zatsepina V.I, Zatsepin E.P, Skomorokhov P.I.: 2019a. „Improving the relability of operation of electromechanical devices by means of ionistor-battery backup". E3S Web of Conferences, Volume 124, 2019. International Scientific and Technical Conference Smart Energy Systems 2019 (SES2019) Article Number 05064, Number of page(s) 5.

Behnamfard, A., Salarirad, M.M., Veglio, F., 2013. Process development for recovery of copper and precious metals from waste printed circuit boards with emphasize on palladium and gold leaching and precipitation. Waste Manag. 33, 2354-2363. https://doi.org/https://doi.org/10.1016/j.wasman.2013.07.017

Cui, J., Zhang, L., 2008. Metallurgical recovery of metals from electronic waste: A review. J. Hazard. Mater. 158, 228-256. https://doi.org/https://doi.org/10.1016/j.jhazmat.2008.02.001

Drechsel, C., 2006. Mechanical processes for recycling waste electric and electronic equipment with the rotorshredder and rotor impact mill 47, 4-14.

Ficeriová, J., Baláž, P., 2010. Leaching of gold from a mechanically and mechanochemically activated waste. Acta Montan. Slovaca 15.

Ficeriová, J., Baláž, P., Gock, E., 2011. Leaching of gold, silver and accompanying metals from circuit boards (PCBs) waste. Acta Montan. Slovaca 16.

Ficeriová, J., Baláž, P., Gock, E., 2005. A processing method of the goldsmith's and electronic Au-Agcontaining wastes. Acta Montan. Slovaca 10.

Fornalczyk, A., Saternus, M., 2013. Platinum recovery from used auto catalytic converters in electrorefining process. Metal. -Sisak then Zagreb. 52, 219-222.

Fornalczyk, A., Willner, J., Francuz, K., Cebulski, J., 2013. E-waste as a source of valuable metals. Arch. Mater. Sci. Eng. 63, 87-92.

Gramatyka, P., Nowosielski, R., Sakiewicz, P., 2007. Recycling of waste electrical and electronic equipment. J. Achiev. Mater. Manuf. Eng. 20.

Havlík, T., Orac, D., Petrániková, M., Miskufova, A., Kukurugya, F., Takáčová, Z., 2010. Leaching of copper and tin from used printed circuit boards after thermal treatment. J. Hazard. Mater. 183, 866-873. https://doi.org/https://doi.org/10.1016/j.jhazmat.2010.07.107

Hsu, E., Barmak, K., West, A., Park, A.-H., 2019. Advancements in the Treatment and Processing of Electronic Waste with Sustainability: A Review of Metal Extraction and Recovery Technologies. Green Chem. 21. https://doi.org/10.1039/C8GC03688H

Islam, A., Ahmed, T., Awual, M.R., Rahman, A., Sultana, M., Aziz, A.A., Monir, M.U., Teo, S.H., Hasan, M., 2020. Advances in sustainable approaches to recover metals from e-waste-A review. J. Clean. Prod. 244, 118815. https://doi.org/https://doi.org/10.1016/j.jclepro.2019.118815

Ivanova T.N., Korshunov A.I., Soldán M., Novokshonov D.N., Bialy W., Baranov M.N.: The Efficiency of Use of Heating Cables in Wells of Complicated Stock. Acta Montanistica Slovaca. ISSN 1335-1788. Volume 23 (2018), number 2, pp. 153-162.

Jang, Y.-C., Townsend, T., 2006. LEACHING OF LEAD FROM DISCARDED NOTEBOOK COMPUTERS USING THE SCALE-UP TCLP AND OTHER STANDARD LEACHING TESTS. Environ. Eng. Res. 11. https://doi.org/10.4491/eer.2006.11.1.014

Kaya, M., 2016. Recovery of metals and non-metals from electronic waste by physical and chemical recycling processes. Waste Manag. 57, 64-90. https://doi.org/https://doi.org/10.1016/j.wasman.2016.08.004

Li, F., Chen, M., Shu, J., Shirvani, M., Li, Y., Sun, Z., Sun, S., Xu, Z., Fu, K., Chen, S., 2019. Copper and gold recovery from CPU sockets by one-step slurry electrolysis. J. Clean. Prod. 213, 673-679. https://doi.org/https://doi.org/10.1016/j.jclepro.2018.12.161

Liu, W., Ford, P., Uvegi, H., Margarido, F., Santos, E., Ferrão, P., Olivetti, E., 2019. Economics of materials in mobile phone preprocessing, focus on non-printed circuit board materials. Waste Manag. 87, 78-85. https://doi.org/https://doi.org/10.1016/j.wasman.2019.01.044

Ni, K., Wang, T., Gosens, J., Xu, L., Li, Q., Wang, L., Liu, S., 2013. A review of human exposure to polybrominated diphenyl ethers (PBDEs) in China. Int. J. Hyg. Environ. Health 216. https://doi.org/10.1016/j.ijheh.2013.02.002

Otto, S., Kibbe, A., Henn, L., Hentschke, L., Kaiser, F.G., 2018. The economy of E-waste collection at the individual level: A practice oriented approach of categorizing determinants of E-waste collection into behavioral costs and motivation. J. Clean. Prod. 204, 33-40. https://doi.org/https://doi.org/10.1016/j.jclepro.2018.08.293

Petraniková, M., 2008. Treatment of End of Life Computers. Technical University of Košice. 
Qu, Y., Wang, W., Liu, Y., Zhu, Q., 2019. Understanding residents' preferences for e-waste collection in China A case study of waste mobile phones. J. Clean. Prod. 228. https://doi.org/10.1016/j.jclepro.2019.04.216

Romaric, O.E., Ogundiran, M., Sangodoyin, A., Babalola, B., 2019. Ecological Risk and Human Health Implications of Heavy Metals Contamination of Surface Soil in E-Waste Recycling Sites in Douala, Cameroun. J. Heal. Pollut. 9, 190310. https://doi.org/10.5696/2156-9614-9.21.190310

Sverdrup, H., Koca, D., Ragnarsdottir, K.V., 2014. Investigating the sustainability of the global silver supply, reserves, stocks in society and market price using different approaches. Resour. Conserv. Recycl. 83, 121-140. https://doi.org/https://doi.org/10.1016/j.resconrec.2013.12.008

Sviatskii V., Bialy W., Sentyakov K., Repko A.: "Estimation of Quality Indicators of Ecological Thermoplastic Fiber Materials" Acta Montanistica Slovaca. ISSN 1335-1788. Volume 25 (2019), number 1, pp. 14-23.

The Silver Institute, The Materials Focus, 2020. World Silver Survey 2020.

Tripathi, A., Kumar, M., Sau, D., Agrawal, A., Chakravarty, S., Mankhand, T., 2012. Leaching of Gold from the Waste Mobile Phone Printed Circuit Boards (PCBs) with Ammonium Thiosulphate. Int. J. Metall. Eng. 1, 17-21. https://doi.org/10.5923/j.ijmee.20120102.02

Tue, N., Takahashi, S., Annamalai, S., Sakai, S., Tajima, Y., 2013. Environmental contamination and human exposure to dioxin-related compounds in e-waste recycling sites of developing countries. Environ. Sci. Process. Impacts 15, 1326-1331. https://doi.org/10.1039/c3em00086a

Widmer, R., Oswald-Krapf, H., Sinha-Khetriwal, D., Schnellmann, M., Böni, H., 2005. Global perspectives on e-waste. Environ. Impact Assess. Rev. 25, 436-458. https://doi.org/10.1016/j.eiar.2005.04.001

Yazici, E., Deveci, H., Alp, I., Akcil, A., Yazici, R., 2010. Characterisation of Computer Printed Circuit Boards for Hazardous Properties and Beneficiation Studies, XXV International Mineral Processing Congress 2010, IMPC 2010

Zhang, Y., Liu, S., Xie, H., Zeng, X., Li, J., 2012. Current Status on Leaching Precious Metals from Waste Printed Circuit Boards. Procedia Environ. Sci. 16, 560-568. https://doi.org/https://doi.org/10.1016/j.proenv.2012.10.077 